\title{
Floral biology of Sesbania virgata: an invasive species in the Agreste of Paraíba, northeastern Brazil'
}

\author{
Vênia Camelo de Souza ${ }^{2,5}$, Leonaldo Alves de Andrade ${ }^{3}, \&$ Zelma Glebya Maciel Quirino ${ }^{4}$
}

\begin{abstract}
Although reproduction seems to play an important role in the successful invasive strategy of Sesbania virgata, its floral biology is poorly known. We aimed at filling this gap by studying the floral biology of a population of S. virgata in the Agreste of Brazil. Sesbania virgata is a shrub that bears racemose inflorescences. Its flowers are zygomorphic, pedunculate, hermaphrodite, and have a pale yellow corolla, diadelphous androecium, anthers with longitudinal dehiscence, and inconspicuous stigma. S. virgata flowers display three different types of petals: banner $(11.92 \mathrm{~mm})$, wing $(8.27 \mathrm{~mm})$, and keel $(9.3 \mathrm{~mm})$. The flowering peak occurred from November to January. The average number of pollen grains per flower was 22,918 , with a pollen viability of $99.93 \%$. Its anthesis is diurnal and asynchronous. Although $S$. virgata is autogamous, its pollen/ovule ratio suggests that this plant has a mixed reproductive system (xenogamy + autogamy). Continuous flowering, flower morphology, and specialized breeding system are essential to assure the reproductive success of this species in the studied habitat. Sesbania virgata is a food source for flower visitors, due to its continuous flowering and large population. Therefore, it has an effective reproductive strategy that assures its invasion success.
\end{abstract}

Key words: breeding system, pollination, Fabaceae.

\section{Resumo}

A reprodução parece ser uma parte importante da estratégia de invasão bem-sucedida de Sesbania virgata. Apesar disso, a sua biologia floral é pouco estudada. O objetivo do nosso estudo foi preencher esta lacuna no conhecimento estudando a biologia floral de uma população de $S$. virgata no agreste brasileiro. Sesbania virgata é um arbusto que apresenta inflorescências racemosas. Suas flores são zigomorfas, pedunculadas e hermafroditas com corola amarelo-clara, androceu diadelfo, anteras com deiscência longitudinal, e estigma inconspícuo. As flores de Sesbania virgata apresentam três diferentes tipos de pétalas: o estandarte $(11,92 \mathrm{~mm})$, as alas $(8,27 \mathrm{~mm})$ e a quilha $(9,3 \mathrm{~mm})$. A maior intensidade do período de floração ocorreu entre novembro e janeiro. A média de grãos de pólen por flor foi de 22.918, com viabilidade polínica de $99,93 \%$. A antese é diurna e assincrônica. Embora $S$. virgata seja autocompatível, a razão pólen/óvulo sugere a presença de um sistema reprodutivo misto (xenogamia + autogamia) nesta planta. A floração contínua, a morfologia floral, e o sistema reprodutivo especializado são indispensáveis para garantir o sucesso reprodutivo desta espécie no habitat estudado. A sua floração contínua e grande população faz de S. virgata uma fonte de recursos para os visitantes florais. Portanto, esta espécie apresenta uma efetiva estratégia reprodutiva que garante seu sucesso como espécie invasora.

Palavras-chave: sistema reprodutivo, polinização, Fabaceae.

\section{Introduction}

Fabaceae is the third largest and the second most economically important family of Angiosperms (Judd et al. 2009). In Brazil, the family is represented by ca. 190 genera and 2,100 species. It plays an important role as a floristic element in several vegetation types, mainly within the Atlantic Forest, where Fabaceae species stand out for their diversity and abundance (Lima 2000). Despite the richness and ecological

\footnotetext{
${ }^{1}$ This work is a part of the Thesis of the first author presented at PPGA/CCA/UFPB

${ }^{2}$ Universidade Federal da Paraíba, Depto. Ciências Básicas e Sociais/CCHSA, Campus III, 58220-000, Bananeiras, PB, Brazil

${ }^{3}$ Universidade Federal da Paraíba, Depto. Fitotecnia e Ciências Ambientais/CCA, Campus II, 58397-000, Areia, PB, Brazil.

${ }^{4}$ Universidade Federal da Paraíba, Depto. Engenharia e Meio Ambiente/CCAE, Campus IV, R. da Mangueira s.n., Centro, 58297-000, Rio Tinto, PB, Brazil.

${ }^{5}$ Author for correspondence: venia_camelo@hotmail.com
} 
importance of Fabaceae in Brazil, only a few studies have investigated the pollination biology and reproduction of this family (see Agostini et al. 2006; Nogueira \& Arruda 2006; Guedes et al. 2009; Leite \& Machado 2009). This situation is especially true for the invasive species of this family.

Sesbania virgata (Cav.) Pers. is commonly used in restoration programs due to its aggressiveness in terms of growth rate and ability to quickly cover up the soil. This species is native to several areas of Brazil. It occurs mainly in pioneer riparian vegetation of midwestern and southeastern regions (Carpanezzi \& Fowler 1997; Braggio et al. 2002), in Brazilian Savanna (Cerrado) and Atlantic Forest areas (Braggio et al. 2002).

The biological traits of invasive plants influence their colonization success, and studying their reproductive system is particularly important for their management (Blanco 1972; Estes et al. 1983). However, Pyšek \& Richardson (2007) stated that the role of plant traits in biological invasion is highly stage- and habitat-specific. When invasive species are able to set flowers and fruits in human-modified habitats, even in the absence of pollinators, in-depth studies are strongly needed. Self-fertilization assures the perpetuation of those species and thus also plays a role in biologic invasion.

The occurrence of $S$. virgata as invasive in the Brazilian Caatinga is somewhat recent, dating back to no longer than three decades (Andrade 2006). The preferential sites for the species within this biome are riparian forests around reservoirs (Andrade 2013). This species is also considered invasive in other regions of Brazil, and has a negative effect on the structure and diversity of native plant communities in all three study sites along riparian forests of the Paraiba River. In Area II, Salgado de São Félix, state of Paraíba, $S$. virgata had a higher value of importance for the shrub-arboreal layer (Souza 2012).

Studies on other invasive plants have associated invasion success with reproductive strategy, which is consistent with Williamson \& Fitter (1996). For instance, characteristics such as independence of pollinators, large fruit set, and fast fruit ripening can facilitate the permanence of another plant species, Ipomoea eriocalyx, in invaded environments. Studies on floral biology, phenology, pollination mechanisms, and breeding systems in species of the Caatinga have been carried out since 1990 (Machado \& Lopes 2002;
Leite \& Machado 2009). Such studies comprised mainly invasive species whose breeding systems take part in the invasion strategy. One example is Raphiodon echinus, typically found in the Sertão of Pernambuco, especially in temporarily flooded areas, road margins, and abandoned crops. Data available suggest that $R$. echinus is autogamous, but needs pollinators to secure its reproductive success (Dias \& Kill 2007).

The breeding system of each species is crucial to assure the perpetuation of its descendants and enable the colonization of new habitats and the occurrence of natural evolutionary processes. Analyzing floral biology and pollination mechanisms is very important (Silva \& Pinheiro 2007), especially in the case of species with invasive potential. In this sense, knowledge of floral morphology, pollination, and breeding mechanisms will contribute to set the ground for the control and management of this species. The present study, therefore, aimed at analyzing the floral biology of $S$. virgata in a population located in northeastern Brazil, to help understand how reproduction integrates the species invasion strategy.

\section{Materials and Methods}

Study area

The present study assessed a natural population of Sesbania virgata in the municipality of Areia, state of Paraíba, northeastern Brazil (06'58'04'S, 35'41'33'W, $527 \mathrm{~m}$ a.s.1.). The area is located in a region known as Brejo Paraibano (ca. 269,424 km²) (IBGE 2011). The climate is mild, with average annual temperatures ranging from 22 to $26^{\circ} \mathrm{C}$. It has a rugged relief where open rainforests predominate (IBGE 1992), and highland swamps are also found.

\section{Species description}

Sesbania virgata is a shrub that reaches up to $6 \mathrm{~m}$ in height, $25 \mathrm{~cm}$ in diameter at breast height $(\mathrm{DBH})$, and $5 \mathrm{~m}$ in crown width. It has a short lifespan (no longer than eight years) and a moderate ability to compete with grasses and resprout from stump after pruning or fire. It grows spontaneously on humid soils and can be associated with Rhizobium (Carpanezzi \& Fowler 1997). Its fruits are nucoid, indehiscent, their color changes from green to opaque brown during the ripening, and they show a dry texture associated with rough skin. Their average values are $5.81 \mathrm{~mm}$ in length, 7.82 in width, and 5.81 in thickness. The seeds (ca. 
4.44 per fruit) are reniform, light chestnut-brown with a smooth, glossy, and hard seed coat. Their average values are $6.87 \mathrm{~mm}$ in length, $4.4 \mathrm{~mm}$ in width, and $3.22 \mathrm{~mm}$ in thickness. The average weight of 1,000 seeds is $7.78 \mathrm{~g}$. The germination is epigeal, and the seedling bears proto-leaves composed of 4-9 leaflets and a sub-woody, white or brown radicle (Araujo et al. 2004).

\section{Data collection}

Data collection and analysis were carried out from April to December 2010. We randomly sampled ten individual plants for analyzing their floral biology.

For the analysis of floral morphology, we fixed the flowers in ethanol $70 \%$ and took them to the Laboratory of Plant Ecology at the Campus IV of the Federal University of Paraiba (UFPB) at Rio Tinto. The data recorded included: flower morphology, flower biometry, anthesis, breeding system, pollen viability, number of pollen grains, and flower visitors. We measured the size of the floral elements of 30 flowers ( 3 flowers per plant, ten plants) with a digital caliper. We collected
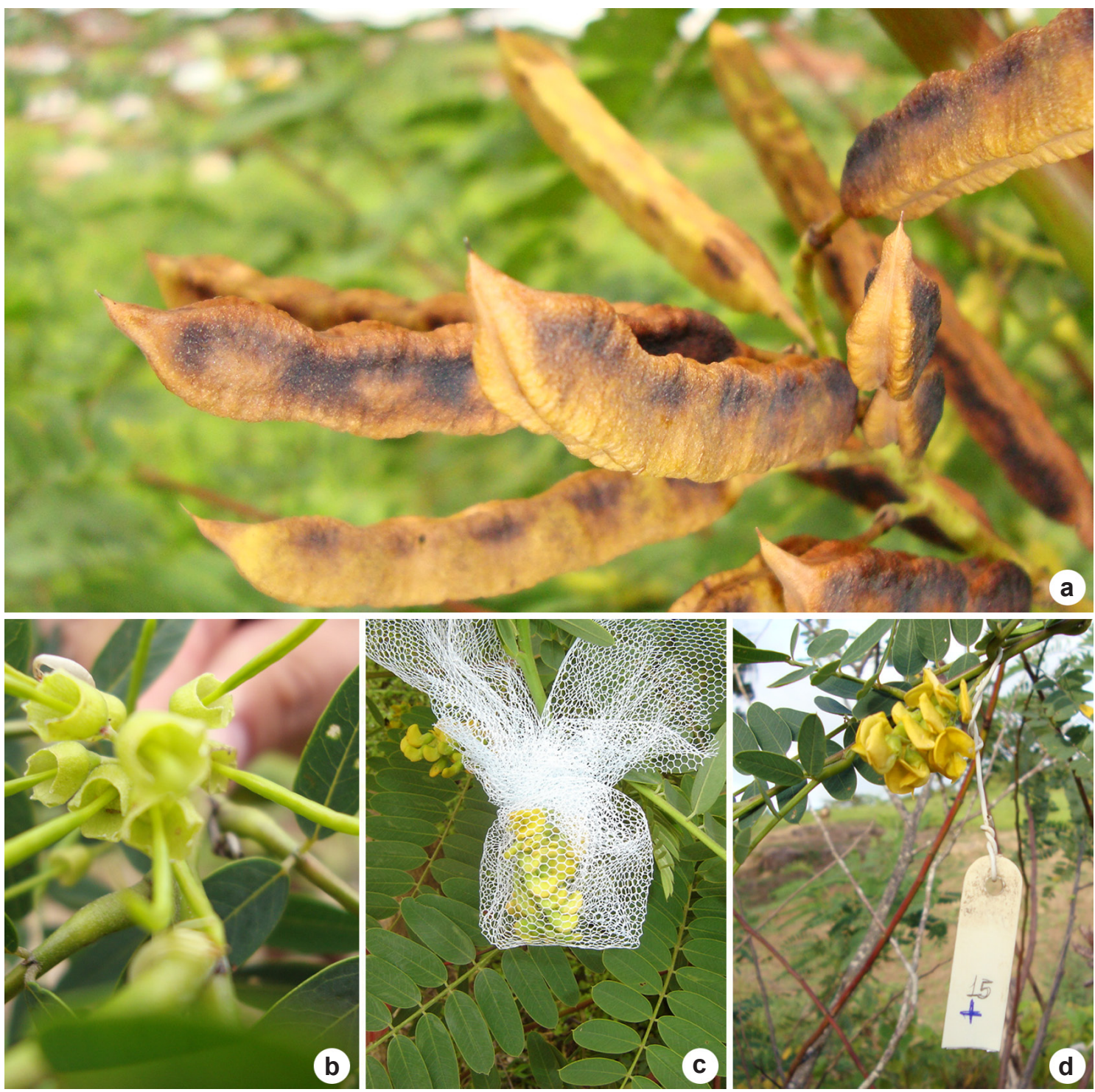

Figure 1 - Pollination experiments carried out in Areia, state of Paraíba, northeastern Brazil - a-b. fruit set; c. bagged flowers; d. flower marking. 
inflorescences in the field. Next, we took the inflorescences to the Laboratory of Botany at the Agricultural Sciences Center, municipality of Areia, state of Paraíba, where we analyzed their flower morphology under a stereomicroscope.

We assessed the species' breeding system through pollination experiments (Fig.1) carried out in the field. We marked 20 individual plants and covered 23 inflorescences bearing pre-anthesis flower buds with voile bags to test for spontaneous self-pollination and fruit set. We left additional 23 inflorescences under natural conditions (control group), with flowers exposed to flower visitors. In both groups, we assessed pollination success through fruit yield. We monitored anthesis for five consecutive days. We marked pre-anthesis flower buds and recorded information on anthesis beginning and duration.

We carried out non-standardized observations of flower visitors during anthesis, and photographed the flowers whenever possible.

To compare the number of fruits formed between treatments, we calculated a t test in BioEstat 5.0.

Pollen viability and pollen/ovule ratio

To estimate the pollen viability, we removed the anthers of ten pre-anthesis flower buds and stained them with acetic carmine 2\% (Radford et al. 1974). We considered viable the pollen grains stained in red. We performed pollen grain counting in a Neubauer chamber and determined pollen/ ovule ratio following Cruden (1977). Although the pollen/ovule ratio per se does not prove that a species is autogamous, it corroborates this hypothesis.

\section{Results and Discussion}

Characteristics of the species

Sesbania virgata is a shrub that bears raceme inflorescences. Its flowers are zygomorphic, pedunculate, hermaphrodite, and show a pale yellow corolla, diadelphous androecium bearing anthers with longitudinal dehiscence, and inconspicuous stigma. In S. virgata flowers, three types of petals can be easily distinguishable: banner $(11.92 \mathrm{~mm})$, wings $(8.27 \mathrm{~mm})$, and keel petals $(9.3 \mathrm{~mm})$. The average number of pollen grains per flower was 22,918 , which have high viability: 99.93\% (Tab. 1). Brito et al. (2010) studied the reproductive biology of other Fabaceae species and also reported high pollen viability: $97 \%$ in Sophora tomentosa and $99 \%$ in Crotalaria vitellina. According to Etcheverry et al. (2008), the flowers of Fabaceae species show an intricate architecture. Therefore, pollen reception can only be achieved by highly specialized mechanisms. Although the population studied shows a continuous flowering pattern (Newstrom et al. 1994), a flowering peak occurred in the dry season, from November 2010 to January 2011.

Besides carrying male gametes, the pollen grains are also a protein source for flower visitors and paramount for the reproductive success of plants (Faegri \& van der Pijl 1979). Sesbania virgata shows, on average, 22,918 pollen grains per flower, which makes the pollen one of the most important nutritional resources offered to pollinators.

\section{Anthesis}

The anthesis is diurnal and begins with the banner petal slowly unbending at ca. 10:00.

Table 1 - Floral traits of Sesbania virgata in a population studied in Areia, state of Paraíba, northeastern Brazil.

\begin{tabular}{ll}
\hline Traits & Measurements \\
\hline Length (mm) & $12.7(15,29 \pm 10,25)$ \\
Width (mm) & $3.0(7,94 \pm 1,72)$ \\
Sepals (mm) & $5.1(5,96 \pm 3,56)$ \\
Peduncle (mm) & $3.8(5,11 \pm 2,36)$ \\
Stigma (mm) & $8.8(10,64 \pm 7,09)$ \\
Pollen/ovule ratio & $4,583.6$ \\
Pollen viability (\%) & $99.93 \%$ \\
Pollen grains (mean value) & 22,918 \\
\hline
\end{tabular}


This process is asynchronous: most flowers are completely open by 12:00, but some flowers begin anthesis only at 14:00. The increase in temperature probably favors anthesis, as its peak occurred around 12:00. The flowers remained open until the following day. Flower opening occurs from the base to the apex of the inflorescence. There are flowers and flower buds at different development stages on the same inflorescence. The extended flower opening favors pollinator activity throughout the day. This strategy may benefit cross-pollination, as it makes the pollen available as a resource in different plants and flowers simultaneously for flower visitors.

The asynchronous pattern seems to be common in some Fabaceae species. Usually, the anthesis is diurnal and lasts only one day (Primack 1985), but some species may show differences in flower duration, as observed in Mucuna sp. flowers (Agostini 2004). Guedes et al. (2009) classified the anthesis of Canavalia brasiliensis Mart. ex Benth (Fabaceae) as diurnal and asynchronous. Souza et al. (2012) classified the anthesis of Senna cana (Fabaceae) as diurnal and very slow. According to the same author, the reproductive success of $S$. cana and its subsequent establishment result not only from the morpho-structural characters of the flower, but also from the vegetative phenology and reproductive strategies.

\section{Breeding system}

Sesbania virgata is autogamous, as fruits were formed in both treatments: control and spontaneous self-pollination (Tab. 2). This result provides evidence that $S$. virgata does not depend on pollinators to transfer pollen grains from the anthers to the stigmatic surface. The pollen grains were already available when the flower bud was closed.

There was a significant difference in fruit set between the control and the treatment of spontaneous self-pollination $(\mathrm{t}=3.0720, \mathrm{p}=$ 0.0018 ). This result suggests that pollinators increased fruit set in this species. The reproductive success was $55.67 \%$ in the control (pollination free from visitors) and $27.34 \%$ in the treatment of spontaneous self-pollination. Aguiar et al. (2012) reported a mixed reproductive system in Oeceoclades maculate composed of crosspollination and autogamy. Similarly to our study species, this system is probably related to its success in colonizing new and isolated habitats.

The population studied showed a continuous flowering pattern. Therefore, a given number of flowers per day on each plant, in a large amount at the peak of the phenophase, could restrict the movement of pollinators. Indeed, we observed few pollinators visiting several flowers per plant, as well as several different plants. Some pollinators were bees (Xylocopa sp.), and we collected them. We bagged flowers after the first visit of pollinators to reduce the pollen flow and avoid additional visits of other pollinators. However, those flowers set fruits. According to Stephenson (1981), this could reduce the pollen flow among plants, which would favor self-pollination.

Autogamy is a reproductive characteristic of invasive and pioneer species that occupy clearings and forest edges (Williamson 1996; Holsinger 2000). In the present study, $S$. virgata individuals occurred in areas similar to clearings, i.e., high-light environments. Repeated cycles of colonization and low density may favor this kind of reproduction to assure the perpetuation of the species (Barret et al. 2008). Although several Fabaceae species are autogamous (Arroyo 1981), there is evidence that cross-fertilization also takes place (Borges 2006).

This strategy assures the maintenance of genetic variability, which is necessary for the permanence of the species in the habitat in the face of environmental pressures that are common in tropical areas. The mesquite tree (Prosopis juliflora), a legume (Fabaceae) of the subfamily Mimosoidae, is another invasive species with a reproductive biology similar to that of $S$. virgata. It has invaded extensive river margins and degraded areas, which resulted in high population density (Andrade et al. 2009; Leão et al. 2011).

Table 2 - Pollination and fruit set in flowers of Sesbania virgata (in each treatment) in Areia, state of Paraíba, northeastern Brazil.

\begin{tabular}{lccc}
\hline Treatments & Flowers/Fruits (Fr/FI) & & Success \% \\
\cline { 1 - 1 } Spontaneous self-pollination & $12.69 / 3.47$ & 27.34 \\
Open pollination (control) & $12.95 / 7.21$ & 55.67 \\
\hline
\end{tabular}


In spite of the fruit set observed in autogamy experiments, the pollen/ovule ratio also suggests $S$. virgata as a preferentially xenogamous plant. However, in self-pollination experiments, we observed the formation of fruits. Therefore, this classification may not be suitable for $S$. virgata, as spontaneous self-pollination also occurs. According to Baker (1974), a certain balance between self-compatibility and cross-pollination is beneficial to weeds. The author states that once a seed is dispersed to a distant place, the formation of a new population will depend on the self-pollination capacity of the species. Sesbania virgata is autogamous, which seems to be a good strategy combined with the ability of this species to invade degraded areas, such as the study site.

Autogamy would work as a safety mechanism to assure reproduction when pollinators are scarce (Endress 1994). Hence, autogamy might contribute to increasing seed set and the species' fitness.

Results indicate that, despite the high pollination efficiency, populations of this rewarding orchid species (Epipactis palustris) were strongly pollen limited. On the other hand, costs of early inbreeding depression were high, which may prevent rapid evolution of complete selfing (Jacquemyn \& Brys 2015).

According to Raven (1996), the appearance of the hermaphrodite flower was an important evolutionary development in Angiosperms. The presence of carpels and stamens in the same flower allows the pollinator to remove and deposit pollen simultaneously. This process increases the efficiency of the pollinator at each visit and, thus, gives a selective advantage to the plant.

\section{Conclusions}

Sesbania virgata is autogamous, which is an important mechanism to assure colonization. The reproductive success and establishment of the species is a result of its reproductive strategy, as well as of its production of flowers/pollen, mainly during the dry season. This strategy is advantageous for the studied species in the marshes ("Brejo") of Paraíba, where the climate is favorable and with no heavy rains that might harm flowers.

\section{Acknowledgements}

We thank the students from the Laboratory of Plant Ecology, especially Francisco Thiago, Ariosto, and Beatriz Symara, for their help during the experiments.

\section{References}

Aguiar, J.M.R.B.V.; Pansarin, L.M.; Ackerman, J.D. \& Pansarin, E.R. 2012. Biotic vs abiotic pollination in Oeceoclades maculata (Lindl,) Lindl. (Orchidaceae: Epidendroideae). Plant Species Biology 27: 86-95.

Agostini, K. 2004. Ecologia da polinização de Mucuna sp. nov. (Fabaceae) no litoral norte de São Paulo, Brasil. Tese de Doutorado. Universidade Estadual de Campinas, Campinas. 97p.

Agostini, K.; Sazima, M. \& Sazima, I. 2006. Bird pollination of explosive flowers while foraging for nectar and caterpillars. Biotropica 38: 674-678.

Andrade, L.A. 2006. Espécies exóticas invasoras no nordeste do Brasil: impactos nos ecossistemas locais. In: Mariath, J.E.A. \& Santos, R.P. (org.). Os avanços da botânica no início do século XXI: morfologia, fisiologia, taxonomia, ecologia e genética. Sociedade Botânica do Brasil, Porto Alegre. 752p.

Andrade, L.A.; Fabricante, J.R. \& Alves, A.D.S. 2008. Algaroba [Prosopis juliflora (Sw.) DC.]: Impactos sobre a fitodiversidade e estratégias de colonização em área invadida na Paraíba. Natureza \& Conservação 6: 61-67.

Andrade, L.A.; Fabricante, J.R. \& Oliveira, F.X. 2009. Invasão biológica por Prosopis juliflora (Sw.) DC. Impactos sobre a diversidade e a estrutura do componente arbustivo-arbóreo da caatinga no estado do Rio Grande do Norte, Brasil. Acta Botanica Brasiliense, 23: 935-943.

Andrade, L.A. de. 2013. Plantas invasoras: espécies vegetais exóticas invasoras da Caatinga e ecossistemas associados. UFPB/CCA, Areia. 100p.

Araújo, E.C.; Mendonça, A.V.R.; Barroso, D.G.; Lamônica, K.R. \& Silva, R.F. 2004. Caracterização morfológica de frutos, sementes e plântulas de Sesbania virgata (CAV.) PERS. Revista Brasileira de Sementes 26: 105-110.

Arroyo, M.T.K. 1981. Breeding systems and pollination biology in Leguminosae. In: Polhill, R.M. \& Raven, P.H. (eds.). Advances in legume systematics: part 2. Royal Botanic Garden, Kew. Pp. 723-769.

Baker, H.G. 1974. The evolution of weeds. Annual Review of Ecology and Systematics 5: 1-24.

Barret, S.C.H.; Colautti, R.I. \& Eckert, C.G. 2008. Plant reproductive systems and evolution during biological invasion. Molecular Ecology 17: 373383.

Blanco, H.G. 1972. A importância dos estudos ecológicos nos programas de controle das plantas daninhas. $\mathrm{O}$ Biológico 38: 343-350.

Borges, H.B.N. 2006. Biologia reprodutiva de Centrosema pubescens Benth. (Fabaceae). Boletim do Museu Paraense Emilio Goeldi Ciências Naturais. Belém. Disponível em <http://scielo.iec.pa.gov. br/scielo.php?script $=$ sci_arttext $\&$ pid $=$ S 1981 $81142006000100003 \& \operatorname{lng}=$ pt\&nrm $=$ iso $>$. Acesso em 3 fevereiro 2016. 
Braggio, M.M.; Lima, M.E.L.; Veasey, E.A. \& Haraguchi, M. 2002. Atividades farmacológicas das folhas de Sesbania virgata (CAV.) PERS. Revista Arquivos do Instituto Biológico 69: 49-53.

Brito, V.L.G.; Pinheiro, M. \& Sazima, M. 2010. Sophora tomentosa e Crotalaria vitellina (Fabaceae): biologia reprodutiva e interações com abelhas na restinga de Ubatuba, São Paulo. Biota Neotropica 10: 185-192.

Carneiro, A.M. \& Irgang, B.E. 2005.Origem e distribuição geográfica das espécies ruderais da Vila de Santo Amaro, General Câmara, Rio Grande do Sul. IHERINGIA, Série Botânica 60: 175-188.

Cruden, R.W. 1977. Pollen-ovule ratios: a conservative indicator of breeding systems in flowering plants. Evolution 31: 32-46.

Carpanezzi, A.A. \& Fowler, J.P.A. 1997. Quebra da dormência tegumentar de sementes de Sesbania virgata (Cav.) Pers. EMBRAPA. Comunicado Técnico, 14. EMBRAPA CNPF, Colombo. Pp. 1-2.

Dias, C.T.V. \& Kiill, L.H.P. 2007. Ecologia da polinização de Raphiodon echinus (Nees e Mart.) Schauer (Lamiaceae) em Petrolina, PE, Brasil. Acta Botanica Brasilica 21: 977-982.

Endress, P.K. 1994. Diversity and evolutionary biology of tropical flowers. Cambridge University Press, Cambridge. 407p.

Estes, J.R.; Amos, B.B. \& Sullivan, J.R. 1983. Pollination from two perspectives: the agricultural and biological sciences. In: Jones, C.E. \& Little, R.J. (eds.). Handbook of experimental pollination biology. Scientific and Academic Editions, New York. 558p.

Etcheverry, A.V.; Alemán, M.M. \& Fleming, T.F. 2008. Flower morphology, pollination biology and mating system of the complex flower of Vigna Caracalla (Fabaceae: Papilionoideae). Annals of Botany, Oxford Journals 102: 305-316.

Faegri, K. \& van der Pijl, L. 1979. The principles of pollination ecology. Pergamon Press, Oxford. 244p.

Guedes, R.S.; Quirino, Z.G.M. \& Gonçalves, E.P. 2009. Fenologia reprodutiva e biologia da polinização de Canavalia brasiliensis Mart. ex Benth. (Fabaceae). Revista Biotemas 22: 27-37.

Holsinger, K.E. 2000. Reproductive systems and evolution in vascular plants. Proceedings of the National Academy of Sciences, USA 97: 7037-7042.

Instituto Brasileiro de Geografia e Estatística. 2011. Cidades. Disponível em <http://www.ibge.gov.br/ cidadesat/painel/painel.php? codmun $=250990>$. Acesso em 7 dezembro 2011.

Instituto Brasileiro de Geografia e Estatística. 1992. Manual técnico da vegetação brasileira. Série manuais técnicos em geociências. Vol. 1. Fundação Instituto Brasileiro de Geografia e Estatística IBGE, Rio de Janeiro. 92p.

Jacquemyn, H. \& Brys, R. 2015. Pollen limitation and the contribution of autonomous selfing to fruit and seed set in a rewarding orchid. American Journal of Botany 102: 67-72.

Judd, W.S.; Campbell, C.S.; Kellogg, E.A.; Stevens, P.F. \& Donoghue, M.J. 2009. Sistemática vegetal: um enfoque filogenético. Artmed, Porto Alegre. 632p.

Leão, T.C.C.; Almeida, W.R.; Dechoum, M. \& Ziller, S.R. 2011. Espécies exóticas invasoras no nordeste do Brasil. In: Leão, T.C.C.; Almeida, W.R.; Dechoum, M. \& Ziller, S.R. (org.). Contextualização, manejo e políticas públicas. CEPAN/Instituto Hórus, Recife. Pp. 21-76.

Leite, A.V. \& Machado, I.C. 2009. Biologia reprodutiva da catingueira (Caesalpinia pyramidalis Tul., Leguminosae-Caesalpinoideae), uma espécie endêmica da Caatinga. Revista Brasileira de Botânica 32: 79-88.

Lima, H.C. 2000. Leguminosas arbóreas da Mata Atlântica: uma análise da riqueza, padrões de distribuição geográfica e similiaridades florísticas em remanescentes florestais do Estado do Rio de Janeiro. Tese de Doutorado. Universidade Federal do Rio de Janeiro, Rio de Janeiro. 151p.

Machado, I.C. \& Lopes, A.V. 2002. A polinização em ecossistemas de Pernambuco: uma revisão do estado atual do conhecimento. In: Tabarelli, M. \& Silva, J.M.C. (eds.). Diagnóstico da biodiversidade de Pernambuco. Editora Massangana, Recife. 722p.

Newstrom, L.E.; Frankie, G.W. \& Baker, H.G. 1994a. A new classification for plant phenology based on flowering patterns in lowland tropical rain forest trees at La Selva, Costa Rica. Biotropica 26: 141159.

Nogueira, E.M.L. \& Arruda, V.L.V. 2006. Fenologia reprodutiva, polinização e sistema reprodutivo de Sophora tomentosa L. (Leguminosae Papilionoideae) em restinga da praia da Joaquina, Florianópolis, sul do Brasil. Revista Biotemas 19: 29-36.

Primack, R.B. 1985. Longevity of individual flowers. Annual Review of Ecology and Systematics 16: 15-37.

Pyšek, P. \& Richardson, D.M. 2007. Traits associated with invasiveness in alien plants: where do we stand? Biological invasions. Nentwig, W. SpringerVerlag Berlin Heidelberg, New York. Pp. 97-122.

Radford, A.E.; Dickison, W.C.; Massey, J.R. \& Bell, C.R. 1974. Vascular plant systematics. Harper \& Row Publishers, New York. 891p.

Raven, P.H.; Evert, R.F. \& Eichhorn, S.E. 1996. Biologia vegetal. Guanabara Koogan, Rio de Janeiro. 728p.

Silva, A.L.G.S. \& Pinheiro, M.C.B. 2007. Biologia floral e da polinização de quatro espécies de Eugenia L. (Myrtaceae). Acta Botanica Brasilica 21: 235-247.

Souza, I.M.; Coutinho, K. \& Funch, L.S. 2012.Estratégias fenológicas de Senna cana (Nees \& Mart.) H.S. Irwin \& Barneby (Fabaceae: Caesalpinioideae) como mecanismo eficiente para atração de polinizadores. Acta Botanica Brasilica 26: 435-443. 
Souza, V.C. 2012. Invasão biológica por Sesbania virgata (CAV) Pers. na Paraíba, Brasil: Biologia reprodutiva, ecofisiologia de sementes e estrutura populacional. Tese de Doutorado. Universidade Federal da Paraíba, Areia. 199p.

Stephenson, A.G. 1981. Flower and fruit abortion: proximate causes and ultimate functions. Annual Review of Ecology and Systematics 12: 253-279.
Sukopp, H. \& Trepl, L. 1987. Extinction and naturalization of plant species as related to ecosystem structure and function. Ecological Studies 61: 245-276.

Williamsom, M. 1996. Biological invasions. Chapman e Hall, London. 256p.

Williamson, M.H. \& Fitter, A. 1996. The characters of successful invaders. Biological Conservation 78: 163-170. 